
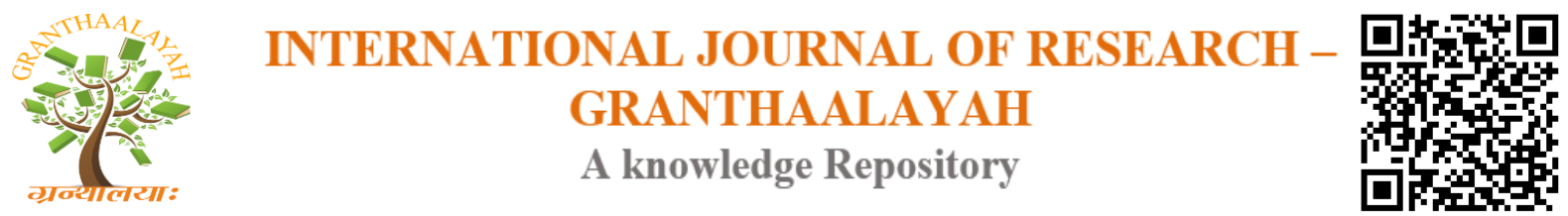

Management

\title{
MASS PATTERNS OF HIGHER EDUCATION IN TAMIL NADU
}

\author{
Dr. S. Rajendran $*^{1}$, K. Udaya Kumar ${ }^{2}$ \\ ${ }^{* 1}$ Professor in Economics, Gandhigram Rural Institute Deemed University, Gandhigram, \\ Dindugal District, INDIA \\ ${ }^{2}$ Ph.D., Research Scholar, Department of Economics, Periyar University, Salem - 636011 , \\ INDIA
}

DOI: https://doi.org/10.29121/granthaalayah.v4.i9(SE).2016.2510

\begin{abstract}
Education plays a vital role for economic development of any nation. It reduces social and economic disparities in society. This study explores the public and private higher educational institutions and literacy level of Tamil Nadu. The literacy rate indicates educational level of total population. Education makes and ushers knowledge economy of a country. The importance of educational service is forever growing in the public and private sectors. Education facilitates the acquisition of new technology, skills and knowledge that ultimately increases productivity in rural and urban areas of India. Public and Private partnership institutions play an important role in delivering educational service in the society and its role for delivering general and technical education for achieving economic development and its producing skill and knowledge of human resource.
\end{abstract}

Keywords:

Education, Human Resources and Educational Institutions.

Cite This Article: Dr. S. Rajendran, and K. Udaya Kumar, "MASS PATTERNS OF HIGHER EDUCATION IN TAMIL NADU", International Journal of Research - Granthaalayah, Vol. 4, No. 9: SE (2016): 57-62.

\section{INTRODUCTION}

Education has been an important factor of economic growth of developing countries. It has contributed to GDP growth in developing nations. India is in third place in the education sector of the world. Education is playing pivotal task on reducing poverty and socio-economic unfairness in rural and urban areas of India. It removes the economic disparities and societal upheavals in the country. The education has been responsible for the human empowerment as well. The economist focuses on economic resources of human capital in a country. The human capital is an important instrument for enhancing productivity for an organization and innovation required to knowledge economy. High skilled labour, semi-skilled and skilled labour forces are 
created by education service and provided to the industrial and service sectors to enhance economic activity.

The importance of educational service is forever growing in India. The public and private sectors contribute to delivering education from primary education to higher education. Education is the basic right of every citizen in India. Mainly, education forms the significance of inclusive growth of the country. Investment in human capital is an important element for sustainable economic development. The technology of education is producing skills, innovative and creative have been the crucial key of digital India. Education facilitates the acquisition of new technologies skills and knowledge that ultimately increases productivity of knowledge economy.

Higher education is a powerful sector of economy growth, enhance productivity, contribute to personal and social development, and reduce social inequality. The higher education institutions need to produce research publications on par with international institutions. While India has large youth population and very less number of higher education institutions function in India. Against the backdrop an attempt is made to discuss the macro dimension of education (higher) in the progressive Tamil Nadu with the following objectives to understand the literacy rates in India and Tamil Nadu, and to analyze the distribution of higher educational institutions in India and Tamil Nadu.

\section{METHODOLOGY}

The present study uses only the secondary data sources which are from various journals and the government reports and websites. Trend of higher educational institutions in Tamil Nadu has been outlined an account of higher education institutions which deliver general and technical educations are explored. Here simple growth rate and percentage for analyzing the higher educational situation at macro level have been employed.

\section{ANALYSIS AND DISCUSSION}

Literacy is conventionally understood as the skill and knowledge to read and write. Literacy has an important role of socio and economic development at urban and rural levels in India. The Registrar General and Census Commissioner of India, defined literacy is "[the ability of] a person aged 7 years and above [to] both write and read with understanding in any language". The table - I indicates literacy rate in India and Tamil Nadu from 1901 to 2011. According to census reports for various years, the literacy rate during 1901 was5.30 percent and at grew to 74.04 percent in 2011. As per the census 2011, 84.1 percent and 67.8 percent of people had ability on read and write skill respectively urban and rural areas.

Table 1: Literacy Rates in India and Tamil Nadu

\begin{tabular}{|l|l|l|l|l|l|l|l|l|}
\hline \multirow{2}{*}{ Years } & \multicolumn{4}{|l|}{ Literacy rates of India } & \multicolumn{4}{l|}{ Literacy rates of Tamil Nadu } \\
\cline { 2 - 9 } & Male & Female & Total & CAGR \% & Male & Female & Total & CAGR \% \\
\hline 1901 & 9.80 & 0.60 & 5.30 & - & 14.10 & 1.00 & 7.60 & - \\
\hline 1911 & 10.60 & 1.10 & 5.90 & 1.8 & 17.10 & 1.50 & 9.20 & 1.93 \\
\hline 1921 & 12.20 & 1.80 & 7.20 & 2.01 & 18.60 & 2.40 & 10.40 & 1.23 \\
\hline 1931 & 15.60 & 2.90 & 9.50 & 2.81 & 20.00 & 2.90 & 11.30 & 0.83 \\
\hline
\end{tabular}




\begin{tabular}{|l|l|l|l|l|l|l|l|l|}
\hline 1941 & 24.90 & 7.30 & 16.10 & 5.41 & 25.60 & 6.90 & 16.20 & 3.67 \\
\hline 1951 & 27.16 & 8.86 & 18.33 & 1.31 & 31.70 & 10.10 & 20.80 & 2.53 \\
\hline 1961 & 40.40 & 15.34 & 28.31 & 4.44 & 51.59 & 21.06 & 36.39 & 5.75 \\
\hline 1971 & 45.95 & 21.97 & 34.45 & 1.98 & 59.54 & 30.92 & 45.40 & 2.24 \\
\hline 1981 & 56.37 & 29.75 & 43.56 & 2.37 & 68.05 & 40.43 & 54.39 & 1.82 \\
\hline 1991 & 64.13 & 39.29 & 52.21 & 1.83 & 73.05 & 51.33 & 62.66 & 1.43 \\
\hline 2001 & 79.56 & 54.28 & 65.38 & 2.27 & 82.33 & 64.55 & 73.47 & 1.6 \\
\hline 2011 & 82.14 & 65.46 & 74.04 & 1.25 & 86.81 & 73.86 & 80.33 & 0.9 \\
\hline
\end{tabular}

Source: Census of India

CAGR-Compound Annual Growth Rate

The census data shows that 82.14 and 65.46 percent male and female were literate in India in 2011. The table illustrated that female literacy rate is very low in India. The literacy rate gap is estimated to 16.3 percent between urban and rural areas. It shows that literacy rate is very low in rural India, due to poor infrastructure facilities in rural India. In Tamil Nadu literacy rate is estimated to 80.33 percent in 2011. Between male and female, 86.81 percent and 73.86 percent was reported in 2011. When compared to current census data male literacy rate grows swiftly but female literacy rates grow slowly. The Government of Tamil Nadu comes to forward to accelerate female literacy. Comparative analysis between the country and the state - Tamil Nadu - the literacy level is far from satisfactory in the state. Even the growth of literacy level is comfortable in Tamil Nadu. This is one of the progressive states to introduce many welfare programme to increase literacy level.

The Indian education system is a large system in the world. Higher education in India has witnessed an impressive growth over the years. Education institutions have an essential responsibility of economic development in India. Tamil Nadu state has some of the most reputed institutes for higher education in India. Following table shows that universities of all India and Tamil Nadu state.

Table 2: Distribution of Universities in India and Tamil Nadu - 2014

\begin{tabular}{|l|l|l|l|l|l|}
\hline S.No & \multirow{2}{*}{ Categories } & India & \multicolumn{2}{l|}{ Tamil Nadu } \\
\cline { 3 - 6 } & & $\begin{array}{l}\text { No. of } \\
\text { Institutions }\end{array}$ & Percent & $\begin{array}{l}\text { No. of } \\
\text { Institutions }\end{array}$ & Percent \\
\hline 1 & Central & 43 & 6.04 & 2 & 3.57 \\
\hline 2 & State & 323 & 45.37 & 21 & 37.5 \\
\hline 3 & Private & 127 & 17.84 & - & - \\
\hline 4 & Deemed & 143 & 20.08 & 28 & 50.00 \\
\hline 5 & Under State Legislative Act & 5 & 0.70 & - & - \\
\hline 6 & National Institutions & 68 & 9.55 & 5 & 8.93 \\
\hline 7 & Others & 3 & 0.42 & - & - \\
\hline 8 & Total & $\mathbf{7 1 2}$ & $\mathbf{1 0 0}$ & $\mathbf{5 6}$ & $\mathbf{1 0 0}$ \\
\hline
\end{tabular}

Source: GOI, Ministry of Human Resource Development

The Indian education system has been widely split over the general education, technical education and professional education. These higher educational institutions are functioning at different fields such as arts, science, humanities, social science, engineering, medical and etc., in 
India. The table -2 shows that an account of 45.37 percent is state universities and following that 20.08 percent and 7.84 percent were deemed and private universities in all over India. Therefore, only 9.55 percent is national institutions like as IIT, IIM and etc. this table is indicate 6.04 percent is central universities and it is extremely not as much of percent in India. However, 0.70 and 0.42 percent were under the state legislative act institutes and other higher educational institutes. The government of India to be starts new central universities and national institutions in remote areas. An accounts of 50.00 percent and 37.5 percent of deemed universities and state universities are located in Tamil Nadu state. The table shows that 8.93 percent and 3.57 percent are national institutions (IIT, IIM and etc.,) and central universities are functioning in Tamil Nadu. These institutions are run by the central government. The state government to be builds new state universities in far-away place.

\section{HIGHER EDUCATION IN TAMIL NADU}

With regard to Tamil Nadu the growth in higher educational service is phenomenal. This state has witnessed a remarkable progress not only in traditional streams like general education and professional education but many colleges have been upgraded as autonomous colleges and even the government colleges obtained autonomous status. However, employability of students like in any other part of the country is a major concern. The growth of higher educational institutions in the arts and science domain is portrayed in table - 3.All private colleges are affiliated to respective universities that are directly under the state government.

Therefore, the state government is able to regulate fees and admission in such institutions. As private sector expanded, the private promoters found control of the affiliating universities, on its part the state government could not fully exploit full market potential in discharging the higher educational service. The table -3 shows that government, constituent, aided and self-finance or unaided colleges. These colleges offer courses especially arts and science, physical education, oriental, school of social work and education. During period 2014-2015 there were 1382 education institutions such as government colleges, aided colleges, self-finance colleges and constituent colleges in Tamil Nadu state.

Table 3: Higher Educational Institutions in Tamil Nadu - 2014

\begin{tabular}{|l|l|l|l|l|l|}
\hline Type of Institution & $\begin{array}{l}\text { Government } \\
\text { Colleges }\end{array}$ & $\begin{array}{l}\text { Constituent } \\
\text { Colleges }\end{array}$ & $\begin{array}{l}\text { Aided } \\
\text { Colleges }\end{array}$ & $\begin{array}{l}\text { Self-finance } \\
\text { Colleges }\end{array}$ & Total \\
\hline $\begin{array}{l}\text { Arts and Science } \\
\text { Colleges }\end{array}$ & $74(10.68)$ & $37(5.34)$ & $139(20.06)$ & $443(63.92)$ & $\mathbf{6 9 3}(\mathbf{1 0 0})$ \\
\hline Physical Education & - & - & $3(27.27)$ & $8(72.73)$ & $\mathbf{1 1}(\mathbf{1 0 0})$ \\
\hline Oriental of Social & - & - & $4(100)$ & - & $\mathbf{4}(\mathbf{1 0 0})$ \\
\hline $\begin{array}{l}\text { School } \\
\text { Work }\end{array}$ & - & $2(100)$ & - & $\mathbf{2}(\mathbf{1 0 0})$ \\
\hline $\begin{array}{l}\text { College } \\
\text { Education }\end{array}$ & $7(1.04)$ & - & $14(2.08)$ & $651(93.88)$ & $\mathbf{6 7 2}(\mathbf{1 0 0})$ \\
\hline Total & $\mathbf{8 1}$ & $\mathbf{3 7}$ & $\mathbf{1 6 2}$ & $\mathbf{1 1 0 2}$ & $\mathbf{1 3 8 2}$ \\
\hline
\end{tabular}

Source: Directorate of Collegiate Education, 2013-14

Table - 3 indicated that there are 1102 private education institutions. The private institutions are having important role in delivering education service for the students. Therefore, private player 
dominated education service in Tamil Nadu which accounts 443 (63.92 per cent) of general educations (arts and science colleges) and 651 (96.88 per cent) of number colleges were college of education and only few (8) numbers of colleges physical education. Shockingly, there is no single physical education college run by the government.

In Tamil Nadu there are162 (12 percent) of colleges were aided institutions and its private institutions financially supported by the government. Therefore, 10.68 percent and 5.34 percent are arts and science colleges and constituent colleges run by the government. There are only 1.04 percent of colleges of education in Tamil Nadu. If the government promotes and sets up an institution, it is referred to as a public institution. On the other hand institutions promoted and set up by private promoters is referred to as private institution. The word private is used interchangeably with non-government and the word public with the government. From the above it is evident that the higher education is steadily going to the group of private investors. Perhaps this is due to the fact that the liberalized market based public policies pushed the private players to their fortune.

Technical Education plays a fundamental role in human resource development of the country and it's producing skilled manpower, enhancing industrial productivity and improving livelihood of its people. Technical education covers programmes in engineering, technology, management, architecture, town planning, pharmacy, applied arts and crafts, hotel management and catering technology. The table - 4 shows technical education in Tamil Nadu. Of total, numbers 577 engineering and 462 polytechnic institutions are reported in Tamil Nadu.

Table 4: Technical Educational Institutions in Tamil Nadu- 2015

\begin{tabular}{|l|l|l|l|l|}
\hline \multirow{2}{*}{ Category } & Engineering & Polytechnic \\
\cline { 2 - 5 } & Frequency & Percent & Frequency & Percent \\
\hline Government Institutions & 10 & 1.73 & 30 & 6.49 \\
\hline Aided Institutions & 3 & 0.52 & 34 & 7.36 \\
\hline Constitute Institutions & 18 & 3.12 & - & - \\
\hline Private Institutions & 546 & 94.63 & 395 & 85.50 \\
\hline Affiliated Institutions & - & - & 3 & 0.65 \\
\hline Total & $\mathbf{5 7 7}$ & $\mathbf{1 0 0}$ & $\mathbf{4 6 2}$ & $\mathbf{1 0 0}$ \\
\hline
\end{tabular}

Sources: Directorate of Technical Education, Tamil Nadu

These accounts for 94.63 percent in engineering and 85.50 percent in polytechnic colleges and are dominated by self-finance institutions. It is noted that 3.12 percent are constituent colleges run by the university. Here only 1.73 percent and 0.52 percent are government institutions and aided engineering institutions and it's very less in the state of Tamil Nadu. This table shows that only 6.49 percent and 7.36 percent were government and aided polytechnic institutions respectively in Tamil Nadu. Clearly, it is evident that Government of Tamil Nadu will establish more education institutions in backward areas.

\section{CONCLUSION AND SUGGESTION}

The study attempted to explore the higher educational institutions in Tamil Nadu state. Higher education (both general and technical) plays essential development of country and it will 
accelerate economic growth of our nation and improvement and development in all the fields. Public and private educational institutions play various roles for delivering the educational service through both general and technical educations. Universities and national institutions are very less in India and Tamil Nadu state. Public players are very less and majority of private holders were dominated in delivering higher educational service.

The public institution may be established in needy areas. Besides, the state shall focus on technical education. Moreover, periodical quality check in delivering system needs to be earmarked for effective delivering of service. The accreditation process shall be scientific and holistic. While encouraging private self-financing institutions, core must be taken to maintained quality. Also mechanism needs to be enforced for governance and accountability.

\section{REFERENCES}

[1] Census of India 2011, www.censusindia.gov.in

[2] Directorate of Technical Education, www.tndte.com/

[3] Golden, S. A. R. (2011). Problems and Prospectus of Distance Learning.Bharathidhasan University, 343, 344.

[4] Golden, S. A. R. (2011). Strategy For Success Of Human Beings:-Time Management.

[5] Higher Education Department - Tamil Nadu of Government,ww.tn.gov.in/department/12

[6] Higher education policy note 2013-2014, Higher Education Department, Tamil Nadu.

[7] Ministry of Human Resource Development, www.mhrd.gov.in

[8] Ministry of Human Resource Development, www.mhrd.gov.in/higher_education 